\title{
FROM ELEMENTARY SCHOOL TO UNIVERSITY EDUCATIONAL PROGRAMMES: A COMPREHENSIVE STUDY OF THE ADULT EDUCATION IN SPAIN
}

\author{
Gonzalo Sacristán-Pérez-Minayo \\ University of Burgos, Burgos, Spain \\ E-mail: gsacristan@ubu.es
}

Ruth María Martín-Moro

Adult Education Centre of Olmedo, Valladolid, Spain

E-mail: rutmmo@yahoo.es

\begin{abstract}
Lifelong learning plays an important role due to the actual needs that we have in terms of knowledgebased economy. It provides education both to working and non-working people who want to be part of this developing society. In this study, two different levels of the Spanish Adult Education are assessed but not only from an individual point of view, but also from the point of view of cooperation between them in order to improve the teaching-learning process. Both the Education Centre of Olmedo (Olmedo, Spain) and the University of Burgos (Burgos, Spain) are described deep inside and likewise, the activities that they two are developing to interconnect both the two centres and the educational levels so that the learning process is never interrupted. Activities such as seminars, web pages management, oral presentations and questionnaires showing different aspects of the educational process will be discussed in the present study. The use of the new Information Technology and Communication (ICT) should be enhanced for effective learning of our adult students. From our results, it will be demonstrated that adults can be part of the education system and therefore gain new skills and knowledge that let them succeed in their lives.

Key words: adult education, developing society, lifelong learning, teaching-learning process, teaching methodology.
\end{abstract}

\section{Lifelong learning}

Adult education is crucial in a developing society and a knowledge based economy. These individuals will gain life and work skills to facilitate their return to the mainstream.

Lifelong learning is developed at all levels of the Spanish education system. At all levels, classes are specifically designed and developed to cater to Adult Education at Elementary Education or below or up to University. There are school counsellors who will guide them which classes to take to further their education and personal development. These individuals have reasonable expectation that the skills and knowledge gained from adult education will help them achieve their goals in life. Programs focused in Adult Education are held around the world, Europe, Spain and the region of Castilla y León in order to include older learners in the learning process.

UNESCO (2009) has worked with Member States since the First International Conference on Adult Education in 1945 to ensure that adults have the basic right to education and in 1976, the UNESCO General Conference approved the Nairobi Recommendation on the Development of Adult Education which enshrined governments' commitment to promote adult education as an integral part of the educational system within a lifelong learning perspective (UNESCO, 2009). 
PROBLEMS

OF EDUCATION

IN THE $21^{\text {st }}$ CENTURY

Volume 51, 2013

114

The European program Grundtvig, which is focused on old learners, tries to involve them into the European society, develop a European awareness and give them an opportunity to reach their working purposes. According to what the program says itself " The Grundtvig programme addresses the teaching and learning needs of those involved in adult education; it aims to provide new learning opportunities for all especially for adults at risk of social exclusion and for older workers. It brings together learners, teachers and organisations in adult education and enables them to exchange experiences, learn from each other and develop new approaches in adult education" (European Commission, 2007).

The Spanish Education Law, in the current LOE (Ley Orgánica de Educación, 2006) states that adult education has the aim of letting any person over 18 years old have the possibility to gain, update, complete or increase their knowledge or skills in order to develop their personal and/or professional career.

The Adult Education Law in the region of Castilla y León stands out that the knowledge society makes necessary Lifelong Learning in order to be up to date due to technological advances and a changing society. Education is the best instrument to improve equal opportunities and labour integration of all the people at risk of social exclusion. It also develops participation of adults in the Castilla y León society (Ley de Educación de Personas Adultas de Castilla y León, 2002).

The Adult Education at Elementary Education levels in Spain is divided into formal and non-formal education. Formal studies include "Level 1" or "Beginning Literacy and Numeracy" and "Level 2" or "Advance Literacy" and non-formal education can include subjects such as: "Distance Secondary Education"(DSE), Foreign Languages and "Information and Communication Technology"(ICT). Formal education is characterised by the possibility of getting a certificate issued in the centre and non-formal studies no certificate is issued in the centre.

The purpose of Level 1 is to help adults to improve their knowledge of the Spanish language, its culture and basic reading, writing and maths skills (ORDEN EDU/1666, 2005).

Level 2 has the objective of helping adults to get the necessary knowledge to be able to enrol in Secondary Education and so that improve their participation in the social, cultural and economic life (ORDEN EDU/1666, 2005).

Non - formal studies try to allow people to get some basic certificates of studies, access to professional training and the development of basic and professional competences (ORDEN EDU/661, 2012).

As regards to University studies, the adaptation to the European Higher Education Space implies the modification of some aspects of the teaching plans (Benito and Cruz, 2005). The teaching-learning processes are based on collaborative work between teachers and students, which requires a new definition of the teaching-learning activities. In the case of adult education, the relationship between teacher - student becomes more important due to the personal proximity to students and therefore more responsibility and commitment to their personal learning. The current number of lectures and seminars should remain at least the same, as before the adaptation to the European Higher Education Space. Teaching/learning methods are changing considerably (Dumoulin, 2004) and it is very important to improve oral communication skills of students (Reitmeier, Svendsen, Vrchota, 2004). The most appropriate methodology of teaching in the subjects of the Microbiology Department of the University of Burgos has been assessed, previously (Sacristán-Pérez-Minayo, Reguera-Useros, Fernández-Muiño, SanchoOrtiz, 2009).

\section{Olmedo Adult Education Centre: Overview}

The Olmedo Adult Education Centre is situated in the region of Castilla y León, in the province of Valladolid. The centre is situated in Olmedo, a village of around 4.000 inhabitants but its classes are given not only in Olmedo but in villages around this area. We teach in 6 villages, Olmedo included, which names, inhabitants and subject per village will be named next: 
- Olmedo (3.845). Subjects: "Level 1", "Level 2", "General English".

- Pedrajas de San Esteban (3.628). Subjects: "ICT", "General English".

- Iscar (6.844) Subjects: "Level 1", "Level 2", "General English", "DSE”

- Mojados (3.295). Subjects: "Level 1", "Level 2",

- La Pedraja de Portillo (1.163). Subjects: "Level 1", "Level 2",

- Valdestillas (1.576) Subjects: "Level 1", "General English",

Formal Studies such as "Level 1" or "Beginning Literacy and Numeracy" and "Level 2" are taught in our centre or "Advance Literacy". Non-formal studies consists of "ICT studies", "General English studies" and "DSE".

As it is an Adult Education Centre, students from 18 years old (number, gender and age of students will be further addressed) can participate in one or two subjects depending on their interests.

"Level 1" is addressed to students which have little knowledge of the Spanish Language, can hardly read or write or even they cannot, and to those who, although they can write or read, they have a lot of difficulties to understand a reading or write about something. We normally have in this class elderly people because of their lack of studies, we will analyse it below. The teaching load is from 2.5 hours to 5 per week.

"Level 2" is for students that have not completed the Elementary Education but they have attended to school for some years and basic language and mathematic skills are already acquired. They also have the history and basic science classes. In them, students review what they learnt years ago and also improve their general knowledge. The teaching load is from 2.5 hours to 5 per week.

"ICT studies for adults" is focused to teach students basic computing and the use of mailing and the Internet. Nowadays illiteracy is not only being unable to write or read but also to use computers, at least, for personal use. One and a half hours per week is the teaching load.

The "General English course" introduces adults into the English language to facilitate them to join courses in the future where they can get a certificate that will help them in their attempt to be part of the working society. One and a half hours per week is the teaching load.

"DSE" is held to give adults the opportunity to get back into the education system and catch up on their studies. Most of them are young students that did not finish the Secondary Education and started to work very early. Some of them want to be promoted or have better jobs and having the opportunity to attend to classes 4 days a week, 2.5 hours a day for two years make it easier as they are able to work and go to classes. After passing the exam, some students join the University or College.

Extracurricular activities such as trips and excursions are considered an important part of the teaching process. These trips developed around the academic year have different objectives:

- To promote interconnection between villages.

- To make subjects more practical as activities are related to what is being studied.

- To open students' minds by getting to know other foreign cultures.

- To achieve a better knowledge of our country and villages.

- To get a sense of European identity.

- To encourage the European dimension.

- To give the opportunity to the elderly to meet other people and visit different places.

Every academic year, according to the planning of activities of the Adult Education Centre of Olmedo, cinema, musicals, theatre, museums and exhibitions are scheduled in order to improve the quality of education. Different cities within Spain are also visited in order to pro- 
PROBLEMS

OF EDUCATION

IN THE $21^{\text {st }}$ CENTURY

Volume 51, 2013

116

mote the Spanish culture (differences and similarities between us) and we travel to a European country as part of the "General English" program so as to raise awareness of the European identity.

\section{University of Burgos: Overview}

The University of Burgos has some adult education programs to improve lifelong learning. Some of these programs are: "Open University to old age", "Experience Interuniversity Program" and "Preparation Courses for the University Entrance Examination for over 25 and 45 years (Course for over 25 and 45 years.)

The "Open University to old age" program is organized by the Student and University Extension Vice-Principalship, University of Burgos. This lifelong teaching program is based on a monographic course intended for adult students. These courses are organized in two different locations, Burgos and Aranda de Duero (Burgos, Spain). The timetables of these courses are: every Monday from 17:00 to 18:30 hours for the Burgos studies and every other Tuesday from 17:00 to 18:30 hours for the Aranda de Duero program.

The teaching plan in Burgos is:

First semester: "Two musical geniuses: Mozart and Beethoven"

Second semester: "The legal protection of the Family: Civil measures and Social Security"

And the teaching plan in Aranda de Duero:

First/Second semester (Academic year): "Musicians, music and life"

The "Experience Interuniversity Program" is an initiative founded by the Junta de Castilla y León Government (Spain) and it is made in collaboration with all the public and private Universities of the Castilla y León Community. The educational program is framed in active aging programs, which aims to give older people the opportunity to access culture and science as a formula for personal growth. People from 55 years old, living in the region of Castilla y León (Spain), could participate in this mentioned program.

The principal objectives are summarized in three:

- To facilitate older people to approach culture and science as a vehicle of expression of experiences and knowledge.

- To promote the exchange of relationships, both between them and the other age groups, becoming the University environment a context of social interaction.

- To encourage occasions for learning and personal growth through reflection and dialogue with classmates and teachers.

The aim of this program is to give students: current knowledge, cultural activities, a teaching methodology adapted to the elderly, the necessary material for each subject and the access to and the use, as a student, of the University facilities. At the end of the three academic years, each student will get a Diploma from the University at which they have been studying.

Each student will make three compulsory and three optional subjects, plus complementary activities. The teaching plan is shown in Table 1. 
Table 1. Teaching plan of the Experience Interuniversity Program from the University of Burgos.

\begin{tabular}{|c|c|c|c|}
\hline \multicolumn{4}{|l|}{ Compulsory subjects } \\
\hline & First year & Second year & Third year \\
\hline & "Psychology" & "Sociology" & "Politics and Society" \\
\hline & $\begin{array}{l}\text { "Interpersonal Communica- } \\
\text { tion" }\end{array}$ & $\begin{array}{l}\text { "Spanish Litera- } \\
\text { ture" }\end{array}$ & "Basic Law" \\
\hline & $\begin{array}{l}\text { "History of Spain and Castilla } \\
\text { y León" }\end{array}$ & $\begin{array}{l}\text { "Ecology and } \\
\text { Environment" }\end{array}$ & "Health and Quality of Life" \\
\hline \multicolumn{4}{|l|}{$\begin{array}{l}\text { Optional subjects } \\
\text { (Each student must choose } \\
\text { one subject per trimester) }\end{array}$} \\
\hline \multirow[t]{4}{*}{ Burgos location } & First trimester & Second trimester & Third trimester \\
\hline & "Notions of economy" & $\begin{array}{l}\text { "Contemporary } \\
\text { Literature" }\end{array}$ & $\begin{array}{l}\text { "Mathematics of everyday } \\
\text { life" }\end{array}$ \\
\hline & $\begin{array}{l}\text { "Cultural traditions of Cas- } \\
\text { tilla y León" }\end{array}$ & "History of Science" & "Archaeology" \\
\hline & $\begin{array}{l}\text { "Greco-Roman culture in } \\
\text { Spain: Art, Language and } \\
\text { Traditions" }\end{array}$ & & \\
\hline \multirow[t]{4}{*}{ Aranda de Duero location } & "Contemporary Literature" & & \\
\hline & "History of Science" & & \\
\hline & "Cinematic Arts" & & \\
\hline & $\begin{array}{l}\text { "Illustrious personages of } \\
\text { Castilla y León" }\end{array}$ & & \\
\hline \multirow[t]{3}{*}{ Miranda de Ebro location } & "History of Science" & & \\
\hline & "Contemporary Literature" & & \\
\hline & "Economy" & & \\
\hline \multirow[t]{3}{*}{ Villarcayo location } & "Economy" & & \\
\hline & "History of Science" & & \\
\hline & "Archaeology" & & \\
\hline
\end{tabular}

The University of Burgos also offers "Preparation Courses for the University Entrance Examination for over 25 and 45 years". This course is for people from 25 to 45 years old who want to enrol at University for the first time and need to pass this exam to be allowed to study here.

The structure and content of the Entrance Examinations are different for students over 25 and for those over 45 years old. For over 25, there is a General phase and a Specific phase with five options: Arts and Humanities; Science; Health Sciences; Social Sciences and Law and Engineering and Architecture. For students over 45, there is a General phase and a personal interview.

Besides, the Microbiology Department has taught, since 2011/2012, a subject ("Agrofood Microbiology") in the Adaptation Courses to the European Credit System (EEES), 
PROBLEMS

OF EDUCATION

IN THE $21^{\text {st }}$ CENTURY

Volume 51, 2013

118 named GAGRIECA, from the Agrofood and Rural Development Engineering Degree of the University of Burgos. The peculiarity of these Adaptation Courses is the age of the students. They are usually people who work in different jobs and want to be updated at the university. They have the previous university degree named "Technical Agricultural Engineers" and through the mentioned Adapted Course, they will be perfectly integrated at the new European Higher Education Space (Bologna Declaration).

The teaching resources used, among others, were: preparation of seminars and analysis of scientific articles (oral presentations, titles proposal and summarizing articles). Visits to agrofood companies and the development of scientific conferences were also part of the complementary activities.

The evaluation of educational activities, both presential and non-presential, was conducted by the Student Satisfaction Survey designed specifically for the Microbiology Department. These questionnaires, specially intended for students, including some sections like the working time spent on each activity, evaluation of resources employed and the appropriate teaching methodology were used during the academic years 2011/2012 and 2012/2013 (Figure 1).

\section{Olmedo Adult Education Centre: Results of the Study}

Number of students, ages, gender and subjects are being analysed in this section. Formal and non-formal education are compared in terms of the number of students and ages.

Figure 2 shows the percentages per subject. A difference in "Advance Literacy", 28\%, can be noticed and points out that this is the most studied subjects in the centre. Nevertheless, were formal education subjects ("Beginning Literacy" and "Advance Literacy") summed up between them and non-formal education ("DSE", "ICT" and "General English"), it could be appreciated that both formal and non-formal have the same amount of students. However, in non-formal education the number of students per subject is very similar.

Figure 3 shows, that in general, students are mostly women except in "DSE" where the number of both men and women attending to classes, is nearly the same.

Students from 50 to 64 are the ones that attend to more classes (Figure 4). They are interested in "Advance Literacy", "General English" and "ICT" subjects. Students from 65 are interested in "Beginning Literacy" and in "DSE" the most part of the students are from 18 to 29 years old.

As regards to the number of male students, there are not notable differences between ages and subjects except in "DSE" (Figure 5).

In "General English" and "ICT", the number of students of this age and gender (women) is half the number of "Advance Literacy" (Figure 6). Students between 50 and 64 are more interested in "Advance Literacy", "General English" and "ICT" and most women above 65 attend to the "Beginning Literacy Classes". In contrast, in "DSE", the students are mostly between 18 and 29 years old (Figure 6). 
Gonzalo SACRISTÁN-PÉREZ-MINAYO, Ruth María MARTÍN-MORO. From Elementary School to University Educational Programmes: A Comprehensive Study of the Adult Education in Spain

PROBLEMS

OF EDUCATION

IN THE $21^{\text {st }}$ CENTURY

Volume 51, 2013

119

Adaptation Course to European Credit System (EEES)

Academic Year 2011/2012. Microbiology Department

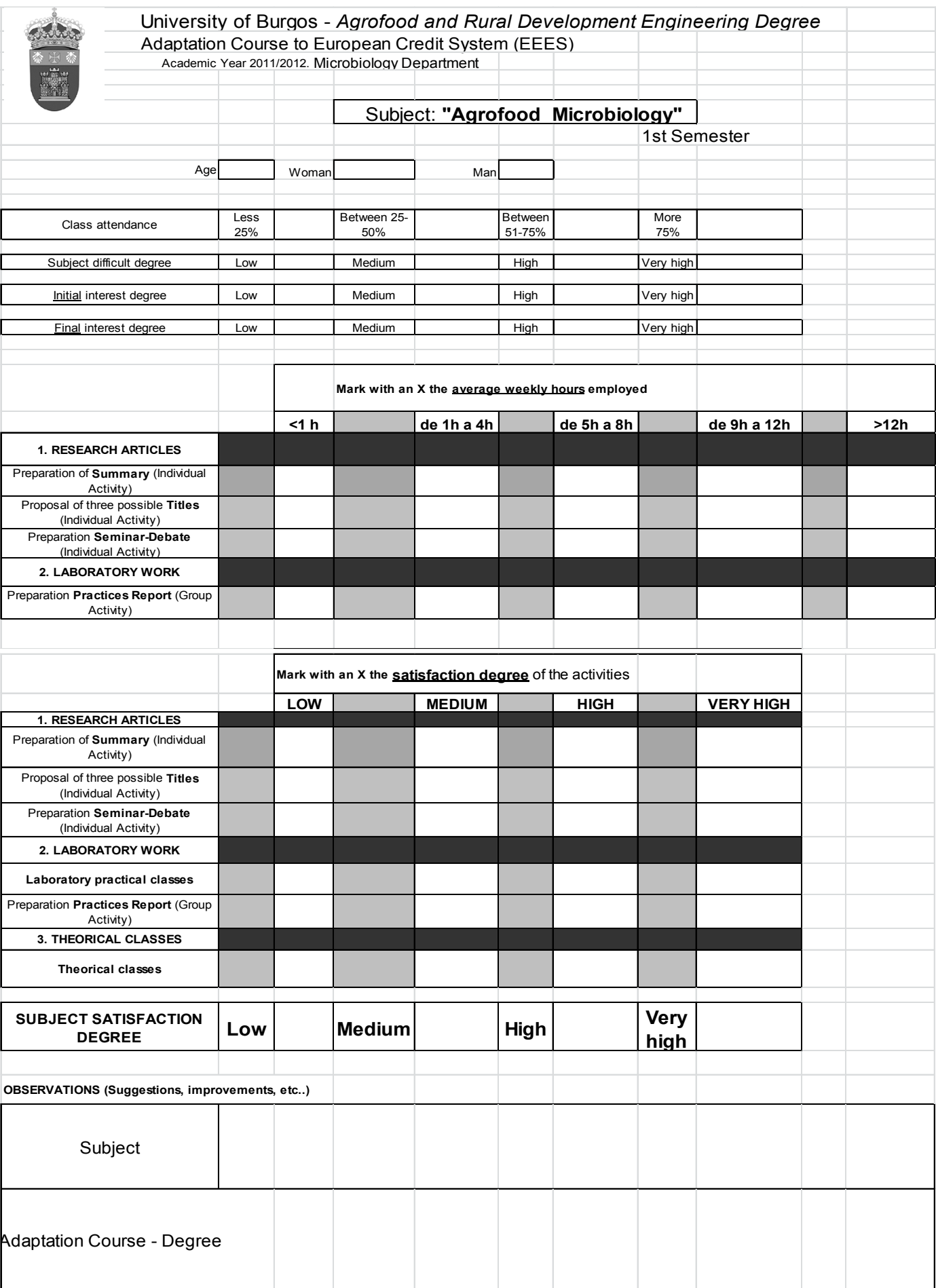

Figure 1: Student Satisfaction Survey Model designed by the Microbiology Department of the University of Burgos. 
PROBLEMS

OF EDUCATION IN THE $21^{\text {st }}$ CENTURY Volume 51,2013

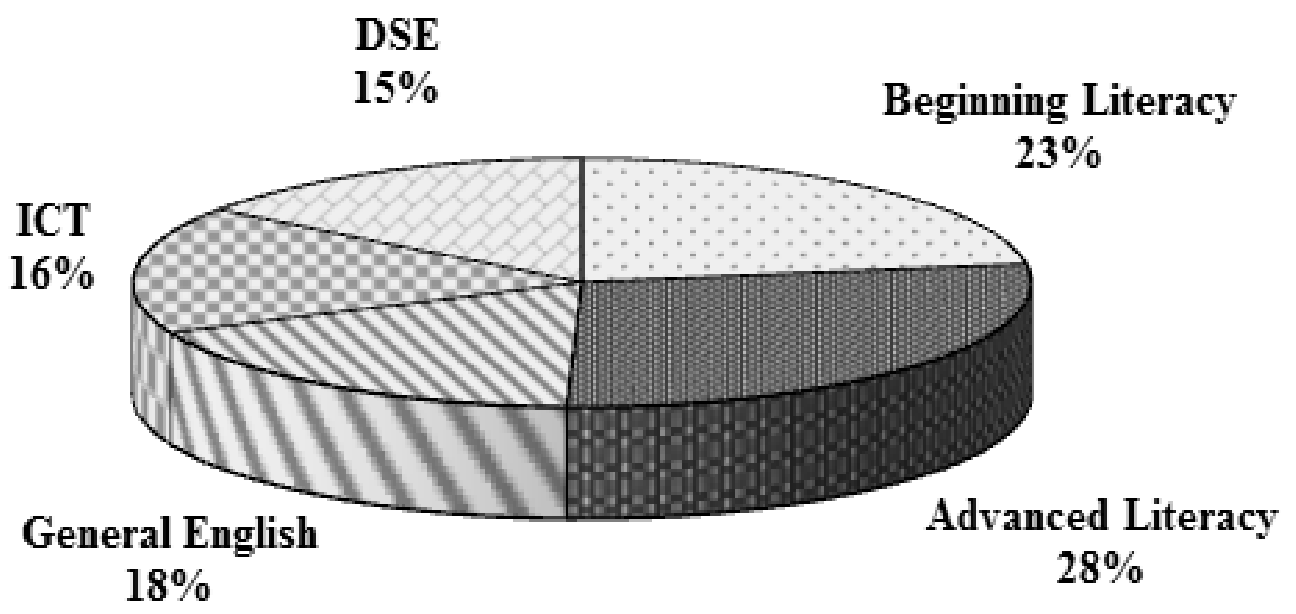

Figure 2: Percentage of students per subject in the adult educational program developed in the Olmedo Adult Education Centre in the 2012/2013 academic year.

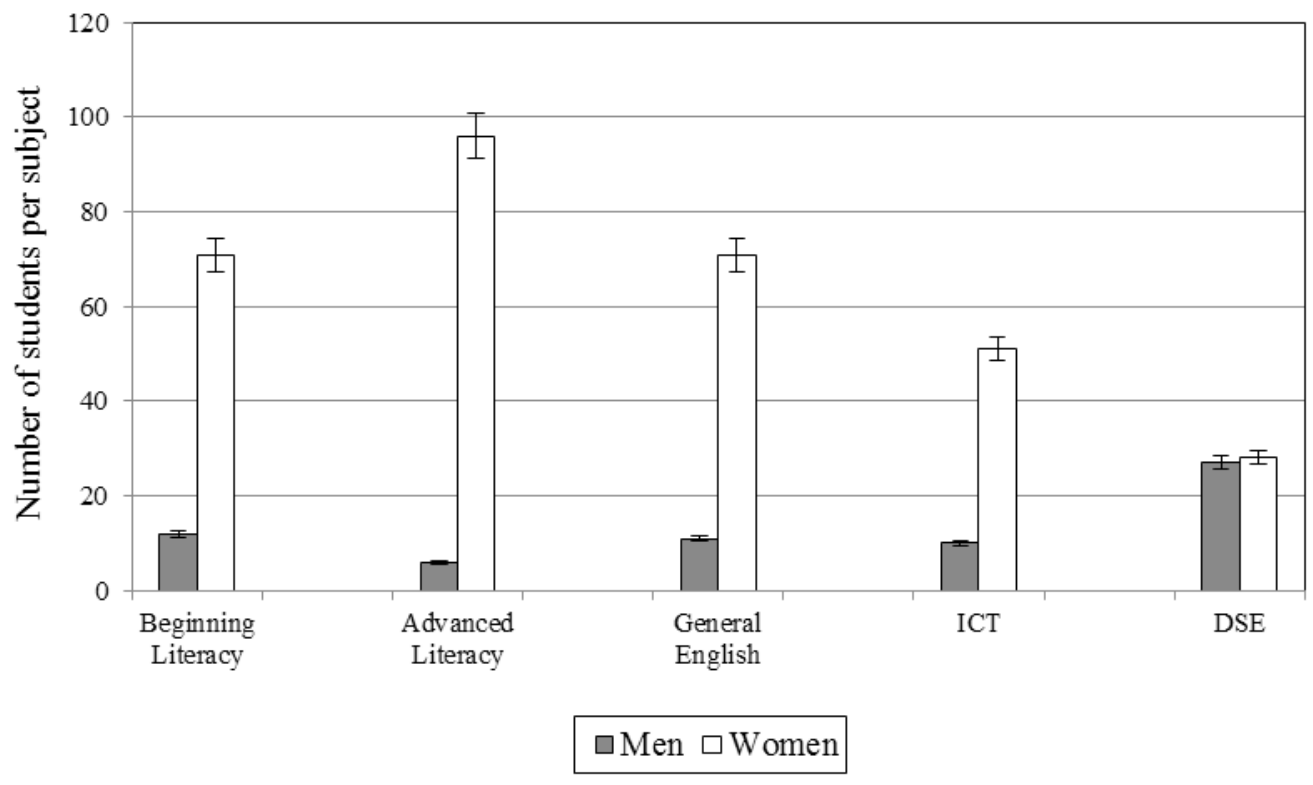

Figure 3: Number students (men and women) attending to different subjects in the Adult Education Centre of Olmedo in the 2012/2013 academic year. 
Advanced Literacy

Beginning Literacy
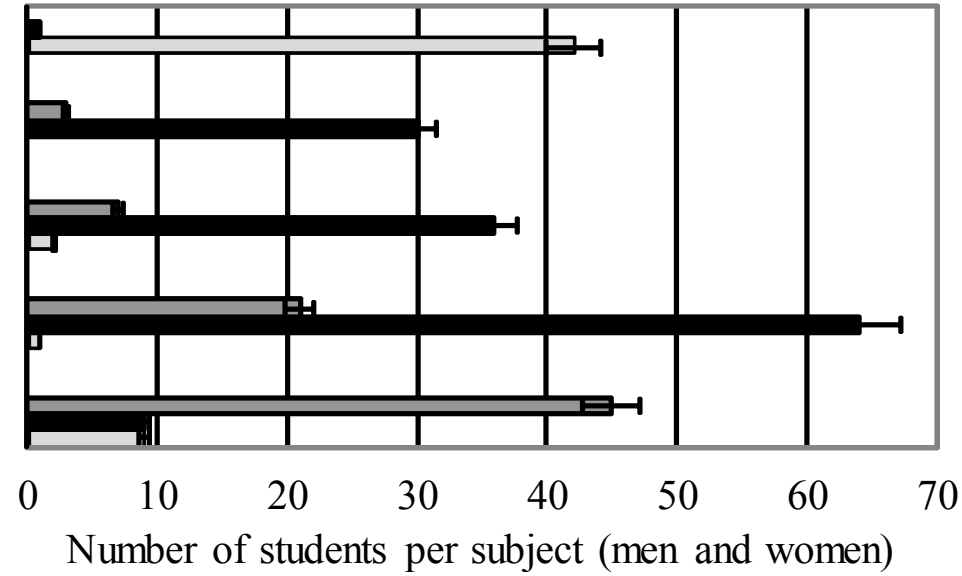

口 65 \& above $\square 50 \& 64 \quad \square 18 \& 29$

Figure 4: Number of students per subject and age (men and women) in the OImedo Adult Education Centre in the 2012/2013 academic year.

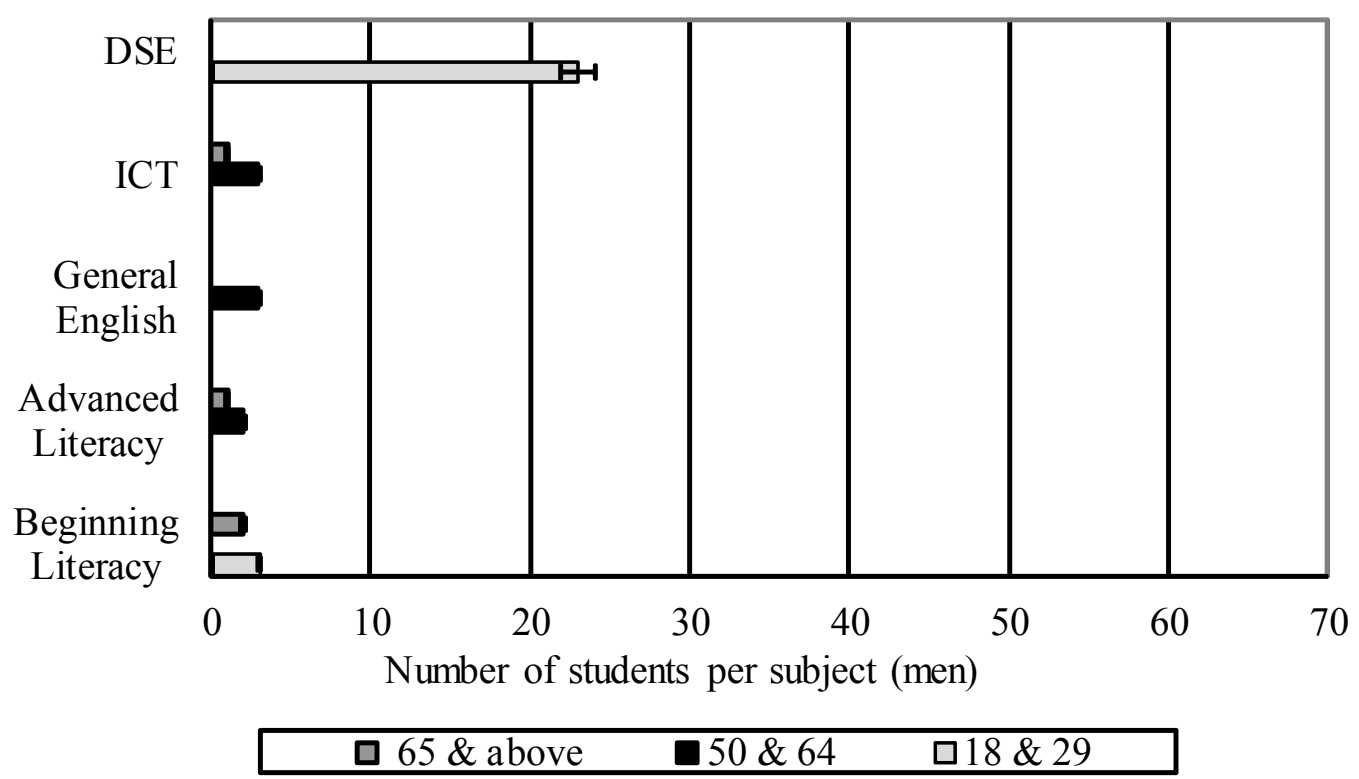

Figure 5: Number of students per subject and age (men) in the Olmedo Adult Education Centre in the 2012/2013 academic year. 
PROBLEMS

OF EDUCATION

IN THE $21^{\text {st }}$ CENTURY

Volume 51, 2013

122

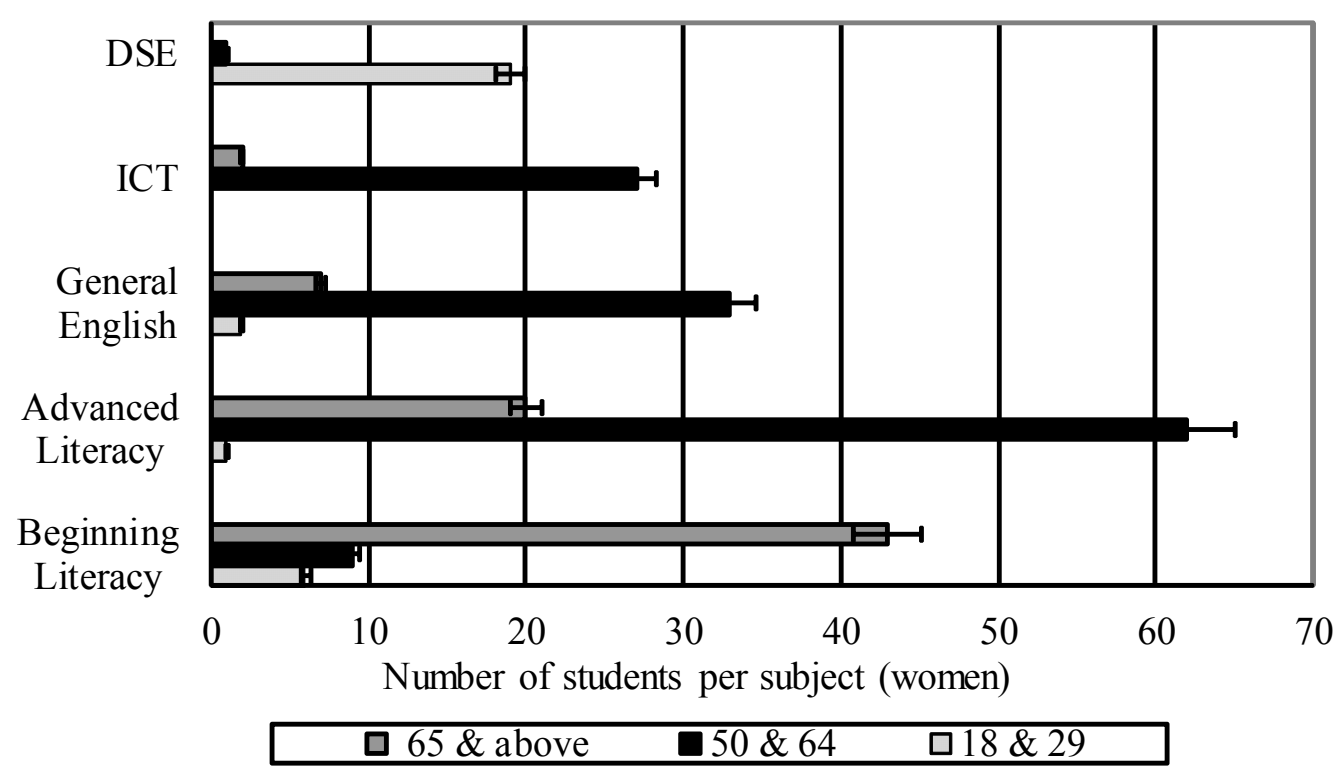

Figure 6: Number of students per subject and age (women) in the Olmedo Adult Education Centre in the 2012/2013 academic year.

\section{University of Burgos: Results of the Study}

The results obtained, during the 2011/2012 and 2012/2013 academic years, from the subject "Agrofood Microbiology" from the Adaptation Course to EEES (GAGRIECA) are shown in Figure 7. The best valoration of the activities, in the 2011/2012 academic year, was for Laboratory practical classes $(90.6 \%)$, after the preparation of Practices Report (84.4\%), Theorical classes (68.8\%), Seminar (59.4\%) and the proposal of Article titles and the Article Summary $(56.3 \%) .81 .3 \%$ of students considered that the development of the subject was very satisfactory (Figure 7a).

As regards to the 2012/2013 academic year, the Laboratory activities were the most valorated ones (preparation of Practices Report, $83.3 \%$ and Laboratory practical classes, $81.3 \%$ ). Later on, the preparation of the Article Summary and the Theorical classes obtained the same valoration (62.5\%). And finally, the least valorated activities were the proposal of Article titles $(56.3 \%)$ and the preparation of the Seminar $(50 \%)$.
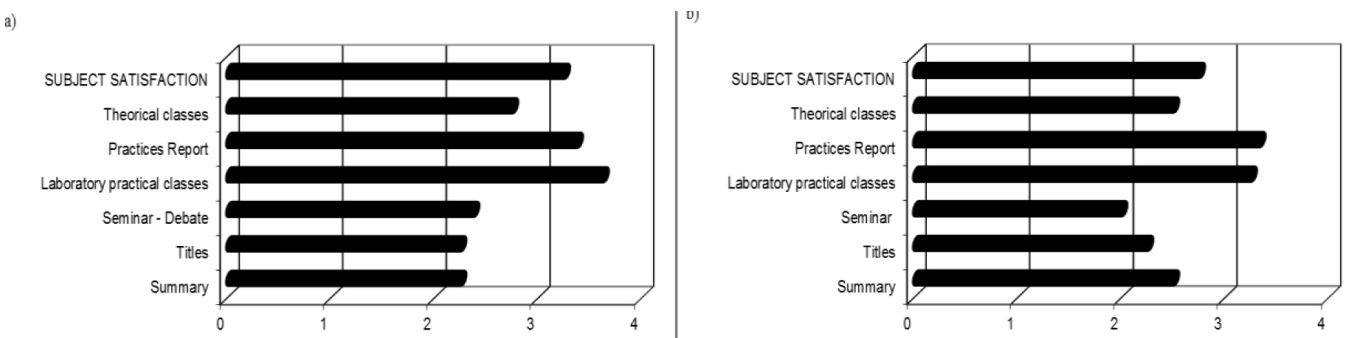

Figure 7: Valoration of the activities performed in "Agrofood Microbiology" subject during the a) 2011/2012 and b) 2012/2013 academic years. 
The Microbiology Department, in collaboration with the Nutrition and Bromatology Department, also held the Scientific Sessions named "Bromatological and Microbiological Aspects in Food Security". In this way, these Scientific Sessions were organized to present the most relevant aspects of food security from the perspective of both microbiological and bromatological points of view. These scientific conferences were intended for all audiences, with a wide range of ages, from food industry professionals and students to the general public.

\section{Discussion}

The national and international development agenda looks at education as an important tool for transformation and change. Within education most attention is given to schooling and the wider formal sector of colleges and universities. Much less attention and still less resources go to youth and adult learning and the non-formal education sector. Lifelong learning systems have yet to be implemented (Duke and Hinzen, 2010). This article (Duke and Hinzen, 2010) describes the major processes, programmes and organizations such as EFA, CONFINTEA, ICAE and discuss them in the context of development issues.

From the results obtained from the subject "Agrofood Microbiology" from GAGRIECA Course (University of Burgos), can be detected the need of using new teaching methods. Among them, the use of the Information and Communication Technologies (ICTs) is a useful educational tool to respond to the training needs, since they reduce the psychosocial and spatiotemporal distance and they facilitate a meaningful and constructive learning (Gisbert, Adell, Rallo, Bellver, 1998).

Similarly to Fernández-Ballesteros, Molina, Schettini, Del Rey (2012), those older adults who follow a university program will improve the core of active aging, which involves cognitive, emotional, and social factors.

Due to the use of ICTs at University, at Elementary school the teaching methods for Adult Education need to be updated. Considering that, we use digital boards and computers in our classes. We also have a special class in which we teach how to use the basic tools to be a general user of this technology. ICTs at the Elementary level for Adult Education is a subject with a remarkable number of students (Figure 4).

Teaching methods in "Advance Literacy" are numerous. We have a lot of students attending to "Advanced Literacy" from 50 to 64, as we could observe in Figure 4. This is because most students between 50 and 64 in the area of the Olmedo Adult Education Centre have attended to school and they are more interested in continuing with their studies. In this subject, students are used to the new technologies because the teacher uses the digital board and the computer on a regular basis. Students take part on presentations and researches in specific materials as history and science and we try to make them use the computers. Normally, it is not an easy task but they are ready to learn and use ICTs, although with more difficulties than younger students. The most part of the students are women (Figure 6) and we can affirm that they are very interested in the use of ICTs in class.

In "DSE" the number of both men and women attending to classes is nearly the same, (Figure 3). This is because they are from 18 to 29. This is also important when we prepare our classes as these students are used to new technologies and it is easier for them to follow and participate in classes using computers. They are more interested in them if we use ICTs as it is something easy for them to manage.

The age of students in "Beginning Literacy" is something to stand out since they are mostly from 65 and above (Figure 4). Considering that most of them did not attend to school or only for a few years, illiteracy is common among them. In these classes the teaching methodology can include some sessions when the digital board is used, for example when we teach them to read or sum up with any of the multiple applications for smart board that you can find in the Internet. Students are not able to handle it on their own, nevertheless, it is required that students get used to ICTs, and with these activities they, at least, know that this technology exists, what reduces the differences on age and time. 
PROBLEMS

OF EDUCATION

IN THE $21^{\text {st }}$ CENTURY

Volume 51,2013

124 Similarly, Hillier (2010) examines the growth of practitioner research in England through the creation of the Learning and Skills Research Network (LSRN) and identifies its effect on subsequent developments in what is generally known as the Lifelong Learning Sector (LLS). Hillier (2010) argues that research in the LLS needs to be designed appropriately but also needs to be undertaken where the intervention and origination of targets and goals is not a political but a sector-led endeavour.

\section{Conclusions}

The aim of the Adult Education is to make adults competent in different subjects and also be an active part of the society. The Adult Education Center of Olmedo and University of Burgos want students to have continuity in their studies and not stop at Elementary School, this is why as part of the teaching program, students are expected to visit the University, take part in workshops and make them interested in continuing with their education. A visit to the University of Burgos could be scheduled so as to provide students of the Centre of Olmedo with experiences that let them realise the possibility at their ages of having a continuing education.

The Teaching methods used in Elementary School will also help them to be encouraged to enrol in University as students will not have such a leap when attending to classes.

\section{Acknowledgements}

The authors would like to thank Álvaro García Prieto (Headmaster of Olmedo Adult Education Centre) for student data, J. Navarro and H. Frey for English revision and to Deanery of the Faculty of Science of the University of Burgos.

\section{References}

Benito, A., Cruz, A. (2005). Nuevas claves para la docencia universitaria en el E.E.E.S. Madrid, Spain: Nancea.

Duke, C., Hinzen, H. (2010). Youth and adult education within lifelong learning: Claims and challenges. Development, 53 (4), 465-470.

Duomoulin, E. (2004). Trends in Food Science Education in Europe. 12th World Congress of Food Science and Technology, Chicago, USA.

European Commission. (2007). Grundtvig: Success Stories - Europe creates opportunities. Luxembourg: Office for Official Publications of the European Communities.

Fernández-Ballesteros, R., Molina, M.Á., Schettini, R., Del Rey, Á.L. (2012). Promoting active aging through university programs for older adults. GeroPsych: The Journal of Gerontopsychology and Geriatric Psychiatry, 25 (3), 145-154.

Gisbert, M., Adell, J., Rallo, R., Bellver, A. (1998). Entornos Virtuales de Enseñanza-Aprendizaje. Cuadernos de Documentación Multimedia. Madrid, Spain.

Hillier, Y. (2010). Critical practitioners, developing researchers: The story of practitioner research in the lifelong learning sector. Journal of Vocational Education and Training, 62 (1), 89-101.

Ley de Educación de Personas Adultas de Castilla y León. (2002). Ley 3/2002, de 9 de abril, de Educación de Personas Adultas de Castilla y León. (BOCyL de 22 de abril de 2002). Junta de Castilla y León: España.

LOE (2006). Ley Orgánica 2/2006, de 3 de mayo, de Educación. (BOE de 4 de mayo de 2006). Ministerio de Educación: España.

ORDEN EDU/1666 (2005). ORDEN EDU/1666/2005, de 13 de diciembre, por la que se ordenan los niveles I y II de la enseñanza básica para personas adultas y se establece su currículo. (BOCyL de 21 de diciembre 2005). Consejería de Educación, Junta de Castilla y León: España.

ORDEN EDU/661 (2012). ORDEN EDU/661/2012, de 1 de agosto, por la que se regulan los programas de educación no formal impartidos en centros públicos de educación de personas adultas de Castilla y León. (BOCyL de 10 de agosto de 2012). Consejería de Educación, Junta de Castilla y León: España. 
Gonzalo SACRISTÁN-PÉREZ-MINAYO, Ruth María MARTÍN-MORO. From Elementary School to University Educational Programmes: A Comprehensive Study of the Adult Education in Spain

Reitmeier, C. A., Svendsen, L. K., \& Vrchota, D. A. (2004). Improving Oral Communication Skills of Students in Food Science Courses. Journal of Food Science Education, 3, 15-20.

Sacristán-Pérez-Minayo, G., Reguera-Useros, J. I., Fernández-Muiño, M. A., Sancho-Ortiz, M. T. (2009). Adaptation of "Bromatology", "Food and Culture", "Microbiology" and "Food Microbiology" subjects lectured at the University of Burgos (Spain) to the European Credit Transfer System. Problems of Education in the 21st Century, 15, 132-138.

UNESCO-Institute for Lifelong Learning. (2009). Global report on adult learning and education. Hamburg, Germany: UNESCO.

Advised by Miguel Ángel Fernández-Muiño, University of Burgos, Spain

Received: January 30, 2013

Accepted: March 14, 2013

\begin{tabular}{l} 
PROBLEMS \\
OF EDUCATION \\
IN THE $21^{\text {st }}$ CENTURY \\
Volume 51, 2013 \\
\hline 125
\end{tabular}
$\mathrm{PhD}$, Assistant Professor, Department of Microbiology, Faculty of Sciences, University of Burgos, Plaza Misael Bañuelos s/n, 09001 Burgos, Spain. E-mail: gsacristan@ubu.es

Website: http://www.ubu.es/ubu/cm

Primary Teacher, Adult Education Centre of Olmedo, PI. Santa María, S/N, 47410 Olmedo, Valladolid, Spain.

E-mail: rutmmo@yahoo.es

Website: http://www.educa.jcyl.es 